\title{
Environmental Parameters for Ecodesign (EPE): applying the tool on paper products
}

\author{
Andréa Franco Pereira ${ }^{1, a}$, Mariana Guimarães Jacinto ${ }^{1}$ \\ ${ }^{1}$ Universidade Federal de Minas Gerais, Department of Architectural and Urban Technology, Rua Paraíba, 697, Belo Horizonte, Brazil
}

\begin{abstract}
This study aims to analyze the parameters of Environmental Labeling Programs in order to systematize the data and information, facilitating the decision making in the design process. The study is based on the importance of the Life Cycle Thinking approach currently in the practice of the design, as well as the need for quantitative targets to achieve environmental goals. The methodology is based on the application of the Environmental Parameters for Ecodesign (EPE) tool. Firstly, a bibliographic revision on the sector of paper products was performed. Secondly, all environmental labeling programs for the product studied - members of the Global Ecolabelling Network - were analyzed in order to apply the EPE tool. The result presents the implementation of the EPE tool for the category of paper products.
\end{abstract}

Keywords. Ecodesign; Product Design; Type-1 Labeling; Environmental Labeling Programs; MSEs.

\section{Introduction}

The environmental issue has been widely considered in recent years by consumers, as well as companies and designers (STEFANO, FERREIRA, 2013).

This concern about the environment foments the increase on the demand for products that induce the reduction of environmental impacts. The environmental acceptance of a product is the symbol of the new century. Thus, concepts such as ecodesign have been part of the strategies of organizations, becoming part of the product design (STEFANO, FERREIRA, 2013).

In ecodesign, environmental aspects are considered as important as any other aspect, such as performance, reliability, symbolic and emotional values, ergonomics and cost. The search is for the development of products with reduced environmental impacts during their life cycle (PÊGO, PEREIRA, CARRASCO, 2012).

With this vision, the designer becomes a major actor in the production of objects with reduced environmental impacts and should, therefore, be marked in certain preexisting parameters (e.g. environmental labeling) that ensure reaching the desired goals.

However, Pêgo, Pereira and Carrasco (2012) observed that, in general, designers do not adopt such parameters, due to the lack of knowledge, or the difficulty in applying them. The authors conclude on the need for the screening, selection and organization of existing parameters, in order to facilitate their understanding and adoption in the project.

In this sense, the EPE tool - Environmental Parameters for Ecodesign is proposed by Pereira and Soares (2016), with reference to the analysis of Environmental Labelling Programs, namely, type I labeling. The objective is to systematize the data and

\footnotetext{
${ }^{\mathrm{a}}$ Corresponding author: andreafranco@ufmg.br
}

information provided through the procedures presented by the Environmental Labeling Programs, and make them available, facilitating decision making in the design process, and directing special attention to the context of Micro and Small Enterprises (MSEs).

Such quantitative and qualitative parameters used in environmental labeling can be systematically used in the design process, ensuring better decision making, considering the product's life cycle, even if obtaining the labeling is not the company's goal.

The article presented here shows the results of research on the utilization of the EPE tool, in order to systematize parameters, broadening its scope for new product categories not yet contemplated. The goal is the development of the digital platform "Environmental Priority", which aims to provide quantitative and qualitative parameters, allowing its use as a tool for ecodesign and transference of information and technology to the productive sector.

Seeking to assist MSEs, studies on the sectors of greatest importance in the state of Minas Gerais were conducted, with current focus on the sectors of timber, metals and paper.

The results presented here show the implementation of the EPE tool for the category of paper products.

Firstly, the methodology adopted included the bibliographic revision on the sector of paper products. Secondly, national and international criteria in Environmental Labeling Programs (Type I) were raised. Finally, these criteria were systematized in accordance with the EPE tool. 


\section{Environmental Parameters for Ecodesign - EPE}

The EPE tool (PEREIRA, SOARES, 2016) is not intended to solely allow designers to meet the criteria of environmental labels, it is intended to allow the criteria used in labeling programs, analyzed and recognized in many countries as relevant for environmental improvements, to be used as parameters for ecodesign even if obtaining the labeling is not the company's goal. Therefore, the criteria need to be organized and systematized in a more practical way to be applied by designers. The EPE tool presents a systematic description of the possible quantitative and qualitative parameters, considered under the perspective of the life cycle thinking of the product. These parameters should be organized as follows:

- Parameter 1: description of the product and raw materials

- Parameter 2: use of hazardous substances

- Parameter 3: surface finishing

- Parameter 4: product assembly

- Parameter 5: end-of-life strategies

\section{Methodology}

The adopted methodology comprised two stages. Firstly, a bibliographic study was conducted on the sector of paper products. There was a search to identify the existence of labeling procedures, initially of the ABNT Environmental program, for product categories of the sector researched. Special attention was given to MSEs in view of the difficulties presented by these companies to adopt environmental parameters to their production, mainly arising from environmental labeling programs.

Next, analyses were conducted on the Environmental Labeling Programs that compose the Global Ecolabelling Network (GEN), in order to meet the specific labeling procedures for the category of paper products, with restrictions to stationery and packaging products. Next, the documents relating to the procedures were carefully considered in order to develop the systematization from the EPE tool.

The production sector of paper products was defined as the second most prominent sector in Minas Gerais, linked to the performance of the design, which procedures are available in Environmental Labeling Programs.

\section{Studies on the paper and cellulose sector}

According to the data from the Food and Agriculture Organization of the United Nations - FAO, between 1970 and 2012, significant changes were observed in the distribution of the production of world cellulose.

Although the first two positions have been occupied by the United States and Canada along the past 42 years, new actors are emerging, especially in the economies that are under development. The case of countries, such as Brazil, Indonesia, Chile and India reflects very well this new configuration of the cellulose geography. Brazil, which in 1970 held the 13th position, skipped to 3rd place in 2012 (SPEROTTO, 2014).

Brazil is the largest producer of short fiber cellulose, because the Brazilian climate is adequate for the planting of eucalyptus, while other countries have a larger production of long fiber cellulose, because the climate is more adequate for pine forests (DEPEC, 2016).

Short fiber cellulose is more absorbent, being used in products with less rigidity, such as paper for printing, writing and tissue. On the other hand, long fiber cellulose is mostly used to manufacture packaging products. The manufacturing of newspaper stock may include the mixture of the two types of cellulose.

In the Brazilian production of paper, $53 \%$ relates to the manufacturing of packaging products, $24 \%$ to printing and writing, $11 \%$ to toilet paper, $7 \%$ to cardboard, $1 \%$ to newspaper stock and $5 \%$ to other types. Most of the production is consumed domestically (DEPEC, 2016).

The leading manufacturers of the market are large, but there are several MSEs engaged in the production of these paper products (ABTCP, 2015; DEPEC, 2016; CNC, 2016)

Minas Gerais has the largest area of planted eucalyptus in Brazil, being the 4th State in relation to cellulose production establishments. With São Paulo in 1 st place, the state occupies the 5th place in the number of paper production establishments. In the production of packaging products and paper products, Minas Gerais occupies the 5th place with 354 establishments (DEPEC, 2016)

The smaller companies tend to fall within a category known as paper producers. They usually buy cellulose from affiliates or third parties (DEPEC, 2016).

Further analysis of the number of producers of cellulose and paper facilities in the State of Minas Gerais $^{1}$ shows the leadership of microentrepreneur establishments in this sector compared to others, such as the rubber, tobacco, leather and chemical sectors. There are 2,052 microenterprises (from 1 to 9 employees) working in the sector of cellulose and paper products, while other sectors have claimed 1,508 and 1,359, respectively. The sector of cellulose and paper is a little under other sectors in the category of small and medium industries. This shows that Minas Gerais has micro, small and medium enterprises with the potential to use the EPE tool, since they are classified within the companies that fail to obtain certification for lacking to understand labeling documents.

Many of these companies work with paper packaging, as reported in the MPE sitemap of the

\footnotetext{
1 - Recent data from the 2015 Annual Information List (RAIS) and the General Register of Employed and Unemployed (CAGED) of the Ministry of Labor and Social Security (MTPS, 2014) were analyzed, provided through contact made with the International Business Analyst of the Federation of Industries of the State of Minas Gerais.
} 
Empresômetro website (CNC, 2016). Paper packaging, as well as the products for writing and printing, fall under the product design category. In this sense, the research analyzed the labeling programs related to these two types of paper products.

\section{Study of environmental labeling programs}

Twenty-six Environmental Labeling Programs, members of the GEN, were studied in order to find out which programs have a specific certification procedure for the category of paper products.

Six out of the 26 programs were chosen, including the Brazilian program ABNT Ambiental. The programs chosen include Ecomark (Japan), EU Ecolabel (European Union), Green Mark (Chinese Taipei) Green Council (Hong Kong) and GECA (Australia).

Every member country of the GEN has a list of certified products. The presence of the category of paper products was analyzed on the website of each labeling program. The procedures in this category included: printing paper, wallpaper, toilet paper, packaging paper, among others.

Some difficulties were encountered during the analysis of the documents of each program studied: some websites and documents did not include the English version (only in the language of the original country, such as the Chinese Green Mark), others lacked information regarding the procedures.

The member countries, which contained the category of paper products, have undergone a screening process of the procedures, in order to leave only the printing, writing, and packaging paper. From the six labeling programs chosen, eight documents were minutely analyzed.

Among the procedures analyzed, one belongs to the Japanese labeling Ecomark (packaging paper - version 3.3), three belong to the EU Ecolabel of the European Union (Converted paper products, Printed Paper and Paper Products), one belongs to the Green Council of Hong Kong (printing paper), and two belong to the Australian GECA (Stationery paper and 'Printing products. Finally, the procedure of the Brazilian program ABNT Ambiental (paper for copying and graphics).

These procedures include paper for writing, printing, copying sold in sheets or rolls, photo paper, newsprint, envelopes, paper bags, notebook, books, magazines, indexes, dividers, advertising materials, catalogs, labels, letter, paper packaging, corrugated boxes, paper for pallets and molded cellulose products. The percentage of paper in the products must be of at least $70 \%$.

After careful reading, each procedure was numbered and compared with each other in order to be systematized in the EPE tool. Many procedures refer to parameters of other policies, which have also been studied and defined as reference in the EPE tool.

\section{Results}

The EPE tool aims to present organized environmental, quantitative and qualitative parameters described in a didactic and readable way, to be effectively applied by designers. Therefore, the parameters must be systematized under the perspective of the life cycle thinking of the product, including product description and raw material, utilization of hazardous substances, surface finishing, product assembly and end-of-life strategies.

Table 1 below shows its application in the category of paper products.

Table 1. EPE applying on paper products.

\begin{tabular}{|c|c|}
\hline $\begin{array}{l}\text { Parameter 1: Description of the } \\
\text { product and raw material }\end{array}$ & Reference \\
\hline $\begin{array}{l}\text { 1.1 The products must have the } \\
\text { following content on recycled paper: } \\
\text { Paper for packaging and paper bags } \\
(>40 \%) \text {; Cardboard, corrugated boxes } \\
\text { and Paper pallets }(>80 \%) \text {; Molded pulp } \\
\text { products }(100 \%) \text {. }\end{array}$ & $\begin{array}{l}\text { Green Mark } \\
\text { Labeling } \\
\text { Program - } \\
\text { Packaging with } \\
\text { Recycled Paper } \\
\text { (2017, China) }\end{array}$ \\
\hline $\begin{array}{l}\text { 1.2 The fiber source must meet one of } \\
\text { the following procedures: } \\
\text { - At least } 50 \% \text { of recycled fibers } \\
\text { including } 20 \% \text { after consumption; OR } \\
\text { - For virgin wood fibers, it must } \\
\text { originate from a sustainable source with } \\
\text { chain-of-custody certification. }\end{array}$ & $\begin{array}{l}\text { Green Council } \\
\text { Labeling } \\
\text { Program - } \\
\text { Printing Paper } \\
\text { (2010, Hong } \\
\text { Kong) }\end{array}$ \\
\hline $\begin{array}{l}\text { 1.3 Non-fibrous sources can be used in } \\
\text { considerable amounts in the } \\
\text { manufacture of paper, including, for } \\
\text { example, starch, which is primarily. } \\
\text { Starch products should not be derived } \\
\text { from genetically modified materials, for } \\
\text { example certain potatoes and corn } \\
\text { starch. }\end{array}$ & $\begin{array}{l}\text { GECA Labeling } \\
\text { Program - Other } \\
\text { Paper Articles } \\
\text { (2016, Australia) }\end{array}$ \\
\hline $\begin{array}{l}\text { 1.4 Chlorine bleaching should not be } \\
\text { carried out on the virgin pulp used in the } \\
\text { products. }\end{array}$ & $\begin{array}{l}\text { Ecomark } \\
\text { Labeling } \\
\text { Program - Paper } \\
\text { Packing V.3.3 } \\
\text { (2017, Japan) }\end{array}$ \\
\hline $\begin{array}{l}\text { 1.5 The packaging of the product shall } \\
\text { be designed to facilitate recycling and a } \\
\text { reduced environmental load when } \\
\text { incinerated. }\end{array}$ & $\begin{array}{l}\text { Ecomark } \\
\text { Labeling } \\
\text { Program - Paper } \\
\text { Packing V.3.3 } \\
\text { (2017, Japan) }\end{array}$ \\
\hline
\end{tabular}




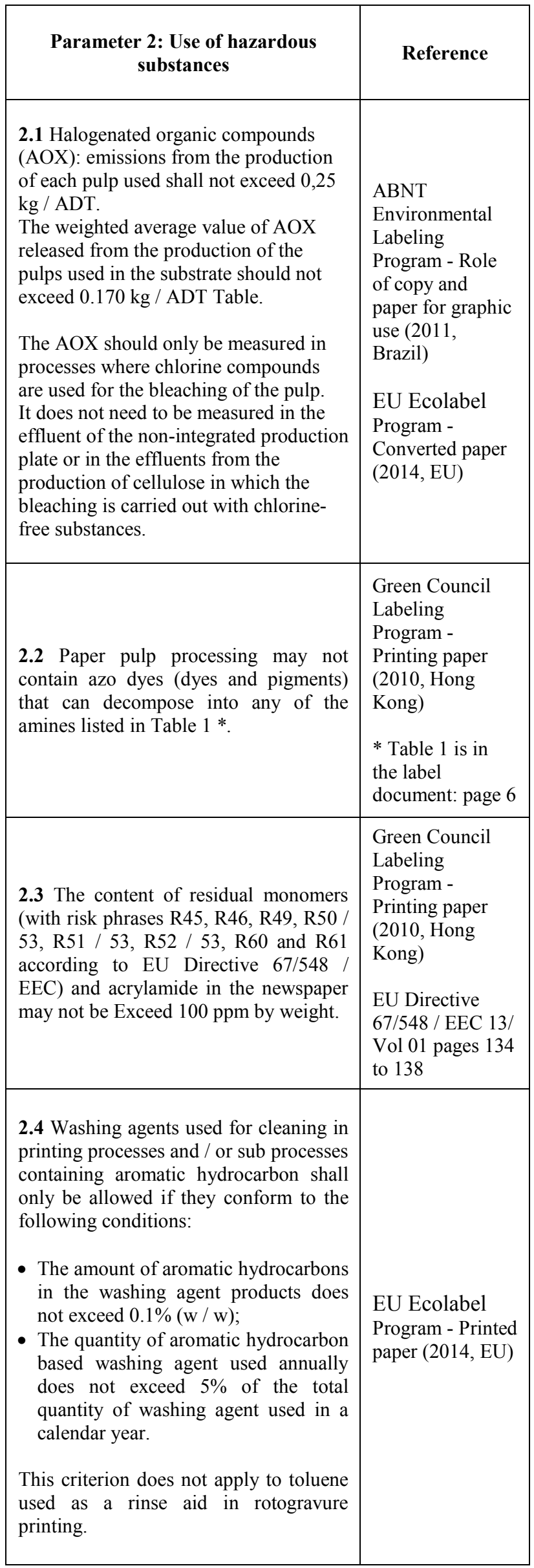

2.5 Volatile solvents from the heat-set of set drying process and flexo printing will be managed by means of collection or combustion or any other equivalent system. In all cases where applicable legislative measures are in place, air VOC emissions shall not exceed $20 \mathrm{mg}$ $\mathrm{C} / \mathrm{Nm} 3$.

This requirement does not apply to screen printing and digital printing. In addition, they do not apply to heat set and flexography installations with solvent consumption of less than 15 tonnes per year.

\section{(n)}

2.6 The substances or mixtures classified as dangerous in the phrases and hazard statements listed below must not be used in the pulp and paper production process or in the production of the final product (where applicable), or be found in the final product: R28, R25, R65 , R39 / 25, R39 / 26, R39 / 27, $\mathrm{R} 39$ / 28, R48 / 20, R48 / 21, R8 / 22, R48 / 25 R52, R51, R51, R51 / 53, R52, R42, R60, R61, R62, R63, R64, R53, R59.

$$
\text { | }
$$

2.7 Adhesives used in the production, conversion or packaging of the product shall not contain ethoxylated alkylphenols or other derivatives of alkylphenols, phthalates (which at the time of application are classified as risk phrases H360, H361), or halogenated volatile organic compounds.

EU Ecolabel Program - Printed paper (2014, EU)

GECA Labeling Program - Other Paper Articles (2016, Australia)

EU Directive 67/548 / EEC 13/ Vol 01 pages 134 to 139

GECA Labeling Program - Other Paper Articles (2016, Australia)

Guidance on the Application of the CLP, Criteria Guidance to Regulation (EC) No $1272 / 2008$ on classification, labelling and packaging (CLP) of substances and mixtures, V.4.1, June/2015. pp. 416

\begin{tabular}{|l|l|} 
& pp. 416 \\
\hline Parameter 3: Surface finish & Reference \\
\hline
\end{tabular}

3.1 Dyes or pigments based on lead, copper, chromium, nickel or aluminum shall not be used. Copper phthalocyanine dyes or pigments may, however, be used.

\section{EU Ecolabel}

Program Converted paper (2014, EU) 


\begin{tabular}{|c|c|}
\hline Parameter 4: Product assembly & Reference \\
\hline $\begin{array}{l}\text { 4.1 Outer packaging shall not be } \\
\text { impregnated, marked, coated or } \\
\text { otherwise treated in a manner which } \\
\text { would prevent recycling (i.e. PVC } \\
\text { sleeves, metal labels). } \\
\text { The packaging must meet at least one of } \\
\text { the following procedures: } \\
\text { - Each constituent material of }>20 \% \text { by } \\
\text { weight of the total primary and } \\
\text { secondary packaging used shall } \\
\text { contain at least } 50 \% \text { recycled material } \\
\text { by weight; } \\
\text { - Each constituent material of }>20 \% \text { by } \\
\text { weight of the total primary and } \\
\text { secondary packaging used must be } \\
\text { derived from herbal materials (e.g. } \\
\text { PLA plastics); OR } \\
\text { - Each separable item constituting } \\
>20 \% \text { by weight of the primary and } \\
\text { secondary packaging shall be } \\
\text { recyclable in own country. } \\
\text { Paper and carton packaging must be } \\
\text { either certified under a recognized forest } \\
\text { certification scheme (e.g. FSC or PEFC) } \\
\text { or contain at least } 30 \% \text { recycled material } \\
\text { by weight. }\end{array}$ & $\begin{array}{l}\text { GECA Labeling } \\
\text { Program - Other } \\
\text { Paper Articles } \\
\text { (2016, Australia) }\end{array}$ \\
\hline $\begin{array}{l}\text { 4.2 The following information should } \\
\text { appear on the paper bags: "Please reuse } \\
\text { this bag" }\end{array}$ & $\begin{array}{l}\text { EU Ecolabel } \\
\text { Program - } \\
\text { Converted paper } \\
(2014, \text { EU) }\end{array}$ \\
\hline Parameter 5: End-of-life strategies & Reference \\
\hline $\begin{array}{l}\text { 5.1 The following criterion applies only } \\
\text { to products where printing and / or other } \\
\text { conversion processes are part of the } \\
\text { manufacturing process for final products } \\
\text { (e.g. converted paper products such as } \\
\text { pastes and pastes). } \\
\text { Washing with water containing silver } \\
\text { film processing as well as sheet } \\
\text { production and chemical photoproducts } \\
\text { should not be evacuated to a sewage } \\
\text { treatment plant. }\end{array}$ & $\begin{array}{l}\text { GECA Labeling } \\
\text { Program - Other } \\
\text { Paper Articles } \\
\text { (2016, Australia) }\end{array}$ \\
\hline $\begin{array}{l}\text { 5.2 The quantity of chromium and } \\
\text { copper discharged to a sewage treatment } \\
\text { plant shall not exceed respectively } 45 \mathrm{mg} \\
\text { per } \mathrm{m} 2 \text { and } 400 \mathrm{mg} \text { per } \mathrm{m} 2 \text { of the surface } \\
\text { area of the cylinder used in the press. }\end{array}$ & $\begin{array}{l}\text { EU Ecolabel } \\
\text { Program - Printed } \\
\text { paper }(2014, \text { EU) } \\
\text { EU Ecolabel } \\
\text { Program - } \\
\text { Converted paper } \\
(2014, \text { EU) }\end{array}$ \\
\hline
\end{tabular}

5.3 The amount of ' $\mathrm{X}$ ' paper waste should not exceed $20 \%$ for envelopes and stationery.

Where, $\mathrm{X}=$ annual kilograms of waste paper produced (processes, including finishing) during the conversion of the converted paper product with label, divided by annual tons of paper purchased and used for the production of ecolabel converted paper product.

- Where the printing house performs finishing processes on behalf of another printing house, the amount of waste paper produced in such processes should not be included in the "X" calculation.

- Where the finishing processes are outsourced to another company, the amount of waste paper resulting from the outsourced work must be calculated and declared in the calculation of the ' $\mathrm{X}$ '
GECA Labeling Program - Other Paper Articles (2016, Australia)

\section{Conclusion}

This study is part of wider research that aims to develop the digital platform "Environmental Priority", which aims to provide quantitative and qualitative parameters, derived from Environmental Labeling Programs (Type I labeling), allowing it to be used in ecodesign and transference of information and technology to the productive sector. Its development is based on the application of the EPE tool - Environmental Parameters for Ecodesign.

The category of paper products was defined as the second most prominent, after the analysis of the productive sectors of interest, using the state of Minas Gerais as reference.

The Environmental Labeling Programs of the Global Ecolabelling Network have been carefully studied with the objective of finding specific certification procedures for the paper product category. The certification procedures were found in the Environmental Programs, such as Labeling Ecomark (Japan), EU Ecolabel (European Union), Green Council (Hong Kong), GECA (Australia) and ABNT Ambiental (Brazil). Each specific criterion, contained in the procedures of the programs analyzed, was organized in accordance with the EPE tool, including materials, hazardous substances, surface finishing, assembly and end-of-life. The text was revised to present the content in a didactic and objective manner in order to make it more comprehensive to designers, micro and small entrepreneurs.

The EPE tool can contribute to ecodesign, as it presents itself as an important device to transfer knowledge to the actors involved in product manufacturing. It translates the complex guidelines set 
by Environmental Labeling Programs and facilitates the access of those interested in taking actions aimed to reduce environmental impacts. Therefore, it can contribute to the reduction of environmental impacts, with the dissemination of information on recognized and recommended environmental practices to be applied in the design of products by companies, especially by MSEs.

\section{Acknowledgements}

Acknowledgements to the CNPq - National Council for Scientific and Technological Development and to the FAPEMIG - Foundation for Research of the State of Minas Gerais for contributing with the resources to perform this research.

\section{REFERENCES}

Associação Brasileira Técnica de Celulose e Papel, ABCTP. Fornecedores e Fabricantes de Celulose e papel 2015/2016. 48 $^{\circ}$ Congresso e Exposição Internacional de Celulose a Papel, 2015. http://www.guiacomprascelulosepapel.org.br/publicador/ edicoes_impressas/8.pdf (Access on: 09 February 2017). Confederação Nacional do Comércio de Bens, Serviços e Turismo, CNC. Empresômetro MPE. http://empresometro.cnc.org.br/ (Access on: 15 December 2016).

Departamento de Pesquisa e Estudos Econômicos, DEPEC. Papel e Celulose. DEPEC/Bradesco, 2016. https://www.economiaemdia.com.br/EconomiaEmDia/p df/infset_papel_e_celulose.pdf (Access on: 08 February 2017).

Ministério do Trabalho e Previdência Social. Anuário

RAIS Estabelecimento Id: Número de Estabelecimentos com Vínculos em 31/12 por Área Geografíca, Subsetor e Faixa de Tamanho do Estabelecimento. RAIS, MTPS, 2014. http://bi.mte.gov.br/scripts10/dardoweb.cgi (Access on: 24 November 2015).

PEGG, K. A. C; PEREIRA, A. F; CARRASCO, E. V. M. Inserção de Parâmetros Ambientais no Desenvolvimento de Produtos: Caso Categoria Móveis de Madeira. Estudos em Design, 2012, Vol. 20, No. 1, pp. 1-24 [online] https://estudosemdesign.emnuvens.com.br/design/article/ view/85/82 (Acessado: 06 February 2017).

PEREIRA, A.F.; SOARES, S.R. Environmental parameters for ecodesign: a tool based on ecolabel programs and life cycle thinking. Int. J. Sustainable Design, Volume 3, Issue 1, DOI: 10.1504/IJSDES.2016.078944, 2016.

SPEROTTO, F. Q. A expansão do setor de celulose de mercado no Brasil: condicionantes e perspectivas. Indicadores Econômicos FEE. 2014, Vol. 41, No. 4, pp. 86 [online] http://revistas.fee.tche.br/index.php/indicadores/article/vi ewFile/3073/3475 (Access on: 09 February 2017).
STEFANO, N.M; FERREIRA, A.R. Ecodesign referencial teórico e análise de conteúdo: proposta inicial para estudos futuros. Estudos em Design, 2013, Vol. 21, No. 2, pp. $02-10 \quad$ [online] https://www.eed.emnuvens.com.br/design/article/view/1 27 (Access on: 06 February 2017). 